\title{
Water Resources of Pointe Coupee Parish, Louisiana
}

\section{Introduction}

Information concerning the availability, use, and quality of water in Pointe Coupee Parish, Louisiana (fig. 1), is critical for proper water-supply management. The purpose of this fact sheet is to present information that can be used by water managers, parish residents, and others for stewardship of this vital resource. In 2014, 364 million gallons per day $(\mathrm{Mgal} / \mathrm{d})$ of water were withdrawn in Pointe Coupee Parish, including about $39.87 \mathrm{Mgal} / \mathrm{d}$ from groundwater sources and $323.72 \mathrm{Mgal} / \mathrm{d}$ from surface-water sources ${ }^{1}$ (table 1). Withdrawals for power generation accounted for 89 percent (323.98 Mgal/d) of the total water withdrawn (table 2). Withdrawals for agricultural use, composed of aquaculture, general irrigation, livestock, and rice irrigation, accounted for 8 percent (29.29 Mgal/d) of the total water withdrawn. Other categories of use included public supply, industrial, and rural domestic. Water-use data collected

${ }^{1}$ Water-withdrawal data are based on estimated or reported site-specific data and aggregated data, which are distributed to sources. For a full description of water-use estimate methodology, see "Data Collection" in Sargent (2011). Tabulation of numbers in text and tables may result in different totals because of rounding; nonrounded numbers are used for calculation of totals. at 5-year intervals from 1960 to 2010 and again in 2014 indicated that water withdrawals peaked in 2014 (fig. 2). The large increase in surface-water withdrawals from 1980 to 1985 is attributable to an increase of $262 \mathrm{Mgal} / \mathrm{d}$ for power-generation use (U.S. Geological Survey [USGS], 2017a).

\section{Groundwater Resources}

The primary freshwater-bearing aquifers in Pointe Coupee Parish are the alluvial aquifer and the Chicot, Evangeline, and Jasper equivalent aquifer systems (fig. 3). In most of the parish, the base of fresh groundwater (water with a chloride concentration of 250 milligrams per liter $[\mathrm{mg} / \mathrm{L}]$ or less) is present in the Jasper equivalent aquifer system at depths ranging from about 300 feet ( $\mathrm{ft}$ ) below the National Geodetic Vertical Datum of 1929 (NGVD 29) in the northern tip of the parish to greater than 2,500 ft below NGVD 29 in the southern part of the parish (fig. 1). In the west-central and southwestern parts of the parish, the base of fresh groundwater is present in the Evangeline equivalent aquifer system at depths ranging from less than $700 \mathrm{ft}$ below NGVD 29 to greater than 2,000 ft below NGVD 29 with some intermediate layers containing saltwater (fig. 1) (Smoot, 1988).

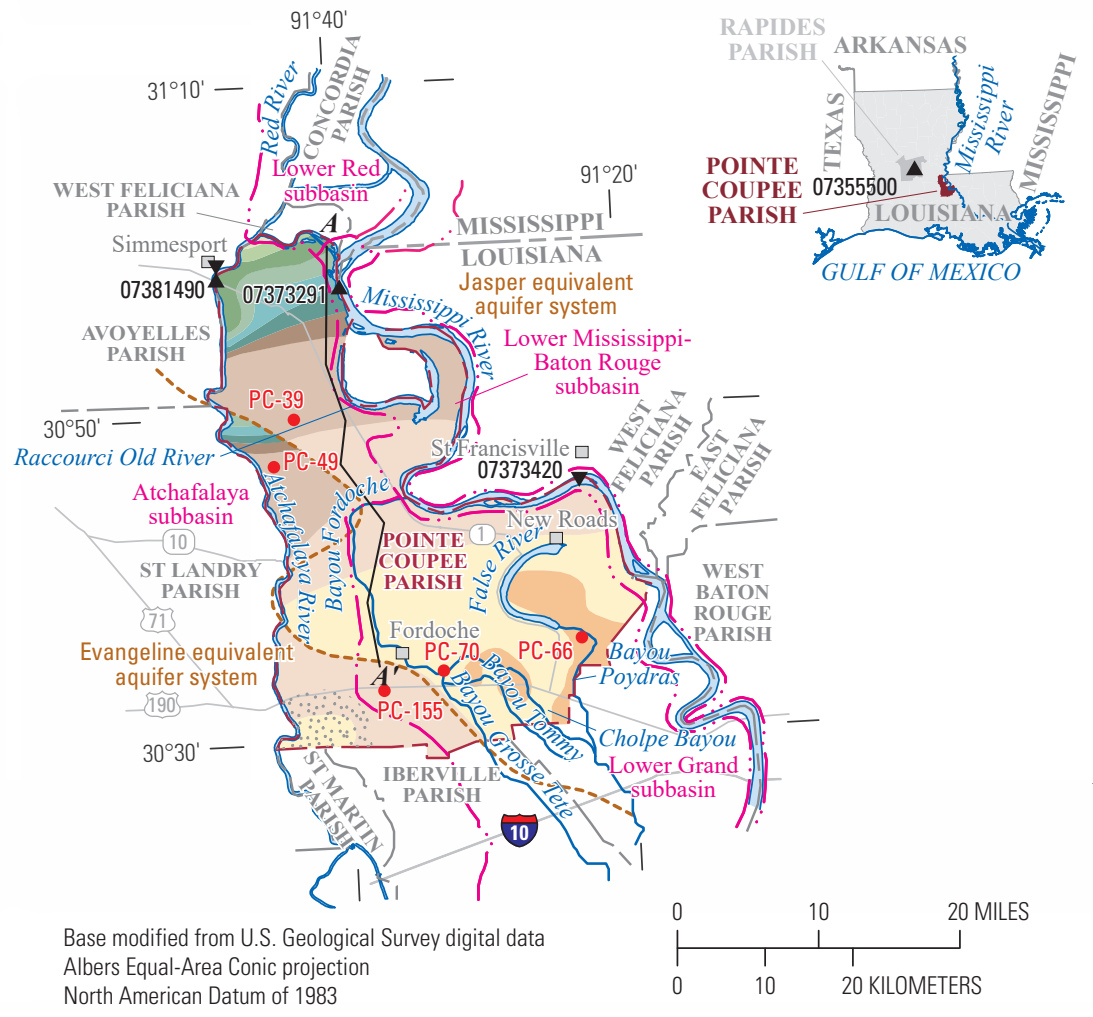

\section{EXPLANATION}

Approximate altitude of base of fresh groundwater, in feet below National Geodetic Vertical Datum of 1929 (NGVD 29) (modified from Smoot, 1988)Deepest freshwater contained within the Jasper equivalent aquifer system, except where noted 300 to 399

400 to 499

500 to 599

600 to 699

700 to 799

800 to 899

900 to 999

1,000 to 1,499

1,500 to 1,999

2,000 to 2,499

2,500 and deeper

Area where intermediate sands contain saltwater

- - - - Approximate boundary of area showing deepest freshwater contained within the overlying

Evangeline equivalent aquifer system (modified from Smoot, 1988)

River subbasin boundary

$A-A^{\prime}$ Line of section (see fig. 3; Griffith, 2003)

Well for which hydrograph is shown (see fig. 4)

U.S. Geological Survey surface-water streamflow $07373291 \quad$ site and number

$\nabla \quad$ U.S. Geological Survey surface-water-quality site 07373420 and number (see table 4)

Figure 1. Location of study area, Pointe Coupee Parish, Louisiana. 
Table 1. Water withdrawals, in million gallons per day, by source in Pointe Coupee Parish, Louisiana, 2014 (Collier, 2018).

\begin{tabular}{lcr}
\hline \multicolumn{1}{c}{ Aquifer or surface-water body } & Groundwater & $\begin{array}{c}\text { Surface } \\
\text { water }\end{array}$ \\
\hline Alluvial aquifer & 28.41 & \\
Chicot equivalent aquifer system & 2.25 & \\
Evangeline equivalent aquifer system & 5.22 & \\
Jasper equivalent aquifer system & 4.00 & \\
Mississippi River & & 322.12 \\
Miscellaneous surface-water bodies & & 1.59 \\
\cline { 2 - 3 } Total & $\mathbf{3 9 . 8 7}$ & $\mathbf{3 2 3 . 7 2}$ \\
\hline
\end{tabular}

Table 2. Water withdrawals, in million gallons per day, by use category in Pointe Coupee Parish, Louisiana, 2014 (Collier, 2018).

\begin{tabular}{lccr}
\hline \multicolumn{1}{c}{ Use category } & Groundwater & Surface water & \multicolumn{1}{c}{ Total } \\
\hline Aquaculture & 6.35 & 1.59 & 7.94 \\
Public supply & 3.49 & 0.00 & 3.49 \\
Rural domestic & 0.23 & 0.00 & 0.23 \\
Industrial & 6.59 & 0.00 & 6.59 \\
Power generation & 1.86 & 322.12 & 323.98 \\
Livestock & 0.01 & 0.01 & 0.01 \\
Rice irrigation & 3.47 & 0.00 & 3.47 \\
General irrigation & 17.88 & 0.00 & 17.88 \\
\cline { 2 - 4 } Total & $\mathbf{3 9 . 8 7}$ & $\mathbf{3 2 3 . 7 2}$ & $\mathbf{3 6 3 . 5 8}$ \\
\hline
\end{tabular}

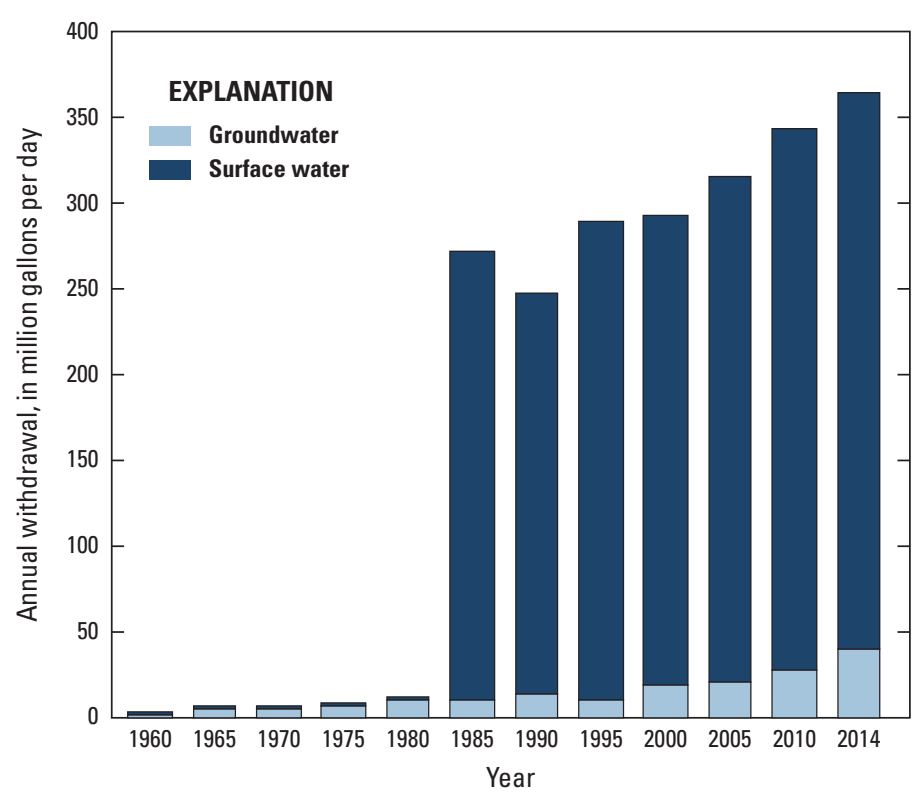

Figure 2. Water withdrawals in Pointe Coupee Parish, Louisiana, 1960-2014 (U.S. Geological Survey, 2017a; Collier, 2018).

\section{Alluvial Aquifer and Chicot Equivalent Aquifer System}

The alluvial aquifer is the shallowest aquifer in the parish and comprises the Mississippi River alluvial and Atchafalaya River alluvial aquifers. Although referred to by different names in different locations, the alluvial aquifer is a single interconnected aquifer that stretches across all of Pointe Coupee Parish (fig. 3). The aquifer grades from gravel and coarse sand near the base to fine sand, silt, and clay at land surface (Winner and others, 1968). The base of the alluvial aquifer ranges from about $125 \mathrm{ft}$ below NGVD 29 in the northern part of the parish to greater than $400 \mathrm{ft}$ below NGVD 29 in the southern part of the parish. Aquifer thickness ranges from about $100 \mathrm{ft}$ in the northern part of the parish to almost $400 \mathrm{ft}$ near the southern border of the parish (Winner and others, 1968).

Water levels in the alluvial aquifer have fluctuated historically with Mississippi River stage (Winner and others, 1968). Water levels at well PC-49 (USGS site number 304645091434901 ) screened in the Mississippi River alluvial aquifer have fluctuated from 1955 to 2017 due at least in part to fluctuations in Mississippi River levels and declined less than about $10 \mathrm{ft}$ during that time (fig. 4).

State well-registration records listed 192 active water wells screened in the alluvial aquifers in Pointe Coupee Parish in 2017: 126 irrigation wells, 43 domestic wells, 20 industrial wells, 2 publicsupply wells, and 1 power-generation well. Well depths ranged from 56 to $325 \mathrm{ft}$ below land surface, and reported yields ranged from 8 to $5,400 \mathrm{gal} / \mathrm{min}$ (Louisiana Department of Natural Resources, 2017). In 2014, $28.41 \mathrm{Mgal} / \mathrm{d}$ were withdrawn from the alluvial aquifers: $15.73 \mathrm{Mgal} / \mathrm{d}$ for general irrigation, $6.35 \mathrm{Mgal} / \mathrm{d}$ for aquaculture, 3.29 Mgal/d for rice irrigation, $2.94 \mathrm{Mgal} / \mathrm{d}$ for industry, $0.08 \mathrm{Mgal} / \mathrm{d}$ for rural domestic, less than $0.01 \mathrm{Mgal} / \mathrm{d}$ for livestock (Collier, 2018).

The Chicot equivalent aquifer system comprises the "400-foot" and "600-foot" sands of the Baton Rouge area (Griffith, 2003; fig. 3). In the northern part of the parish, the aquifer system merges with the overlying alluvial aquifer and is in direct hydraulic connection or has been eroded away and replaced by alluvial deposits. State wellregistration records listed only one industrial well screened in the "600-foot" sand in 2017. The well had a depth of $360 \mathrm{ft}$ and a yield of 535 gallons per minute ( $\mathrm{gal} / \mathrm{min}$ ) (Louisiana Department of Natural Resources, 2017). In 2014, $2.25 \mathrm{Mgal} / \mathrm{d}$ were withdrawn from the Chicot equivalent aquifer system for industry.

\section{Evangeline Equivalent Aquifer System}

The Evangeline equivalent aquifer system is present and contains freshwater in various parishes of southeastern Louisiana and comprises the "800-foot," "1,000-foot," "1,200-foot," "1,500-foot," and "1,700-foot" sands of the Baton Rouge area (Griffith, 2003). The aquifer system dips to the south and as a result progressively subcrops into the alluvial aquifer (fig. 3). This progression results in the deeper sands, such as the "1,700-foot" sand, being present in the furthest north. The base of the aquifer system extends to about 1,600 ft below NGVD 29 in the southern part of Pointe Coupee Parish (Winner and others, 1968).

In 2001, water levels in the "1,200-foot" sand ranged from about $20 \mathrm{ft}$ above NGVD 29 in the central part of the parish to about $10 \mathrm{ft}$ below NGVD 29 in the southeastern part of the parish with a groundwater-flow direction towards the southeast (Griffith and Lovelace, 2003). Water levels at well PC-155 (USGS site number 303250091365001 ) screened in the "1,200-foot" sand have declined about $20 \mathrm{ft}$ from the 1970s to the 2010s (fig. 4). Water levels at well PC-39 (USGS site number 304939091422101) screened in the "1,500foot" sand have fluctuated seasonally and, overall, remained stable from the 1950 s to the 2010 s (fig. 4).

State well-registration records listed 81 active water wells screened in the Evangeline equivalent aquifer system in Pointe Coupee Parish in 2017: 36 public-supply wells, 29 domestic wells, 7 irrigation wells, 4 industrial wells, and 5 power-generation wells. Well depths ranged from 290 to $1,482 \mathrm{ft}$ below land surface, and reported yields ranged from 2 to 2,500 gal/min (Louisiana Department of Natural Resources, 2017). In 2014, about 5.22 Mgal/d were withdrawn from the Evangeline equivalent aquifer system in Pointe Coupee Parish: $2.15 \mathrm{Mgal} / \mathrm{d}$ for general irrigation, $1.86 \mathrm{Mgal} / \mathrm{d}$ for power generation, $0.86 \mathrm{Mgal} / \mathrm{d}$ for public supply, $0.17 \mathrm{Mgal} / \mathrm{d}$ for rice irrigation, $0.12 \mathrm{Mgal} / \mathrm{d}$ for industry, $0.05 \mathrm{Mgal} / \mathrm{d}$ for rural domestic, and less than $0.01 \mathrm{Mgal} / \mathrm{d}$ for livestock (Collier, 2018). 


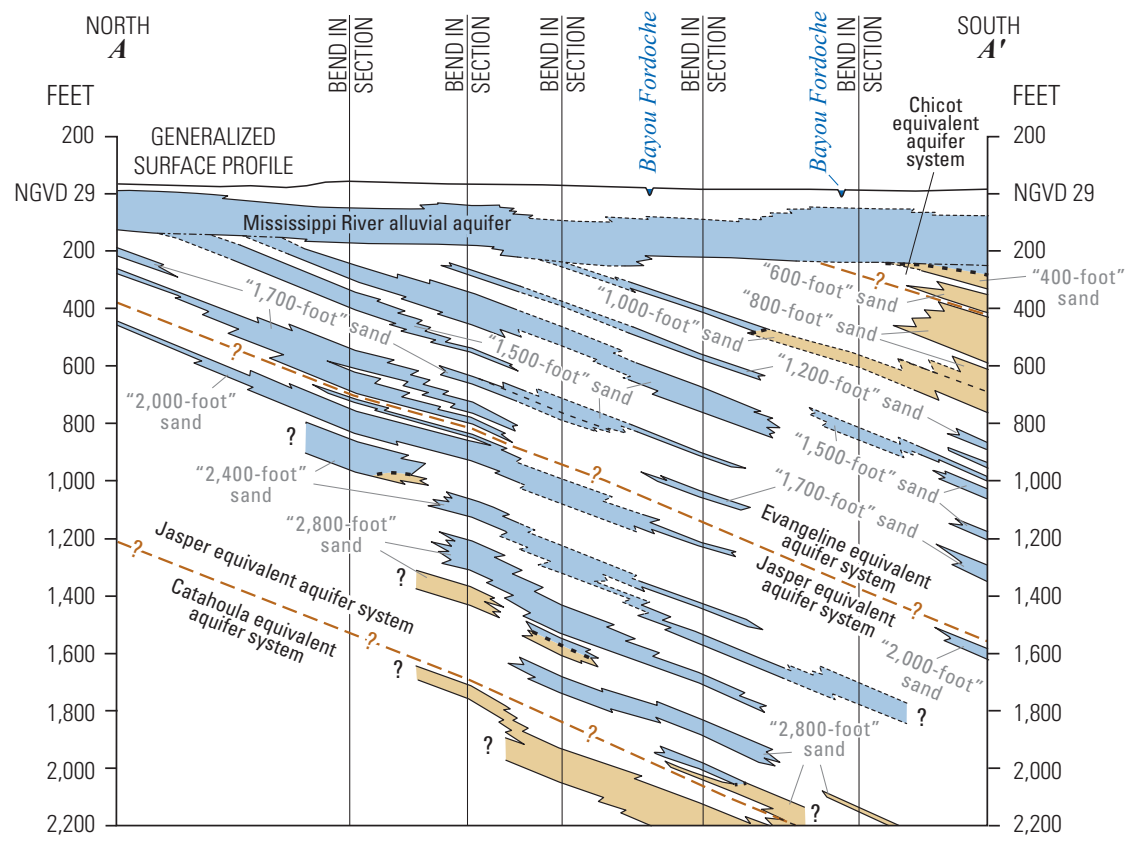

EXPLANATION

Hydrogeologic unit (modified from Smoot, 1988; Stuart and others, 1994; Griffith, 2003)—Water-bearing units local to the Baton Rouge area are named for the approximate depth at which the producing sand occurs beneath the land surface. The local sands comprise the regional aquifer systems. Clay units in the area are discontinuous and unnamed

Aquifer containing freshwater-Freshwater contains a chloride concentration of 250 milligrams per liter or less

Aquifer containing saltwater

Confining unit or confining layer within the aquifer system Lithologic contact (modified from Griffith, 2003)-

Dashed where approximately located. Queried where uncertain

Approximate contact between conjoined or merged Baton Rouge area sands (modified from Griffith, 2003)

Approximate contact between aquifer systems that underlie the Mississippi River alluvial aquifer (modified from Griffith, 2003)—Queried where uncertain

Approximate freshwater/saltwater interface (modified from Griffith, 2003)

NGVD 29, National Geodetic Vertical Datum of 1929

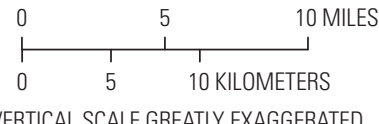

Figure 3. Idealized north-to-south hydrogeologic section through Pointe Coupee Parish, Louisiana, showing aquifer and confining unit intervals. Modified from Griffith (2003). Trace of section shown on figure 1.

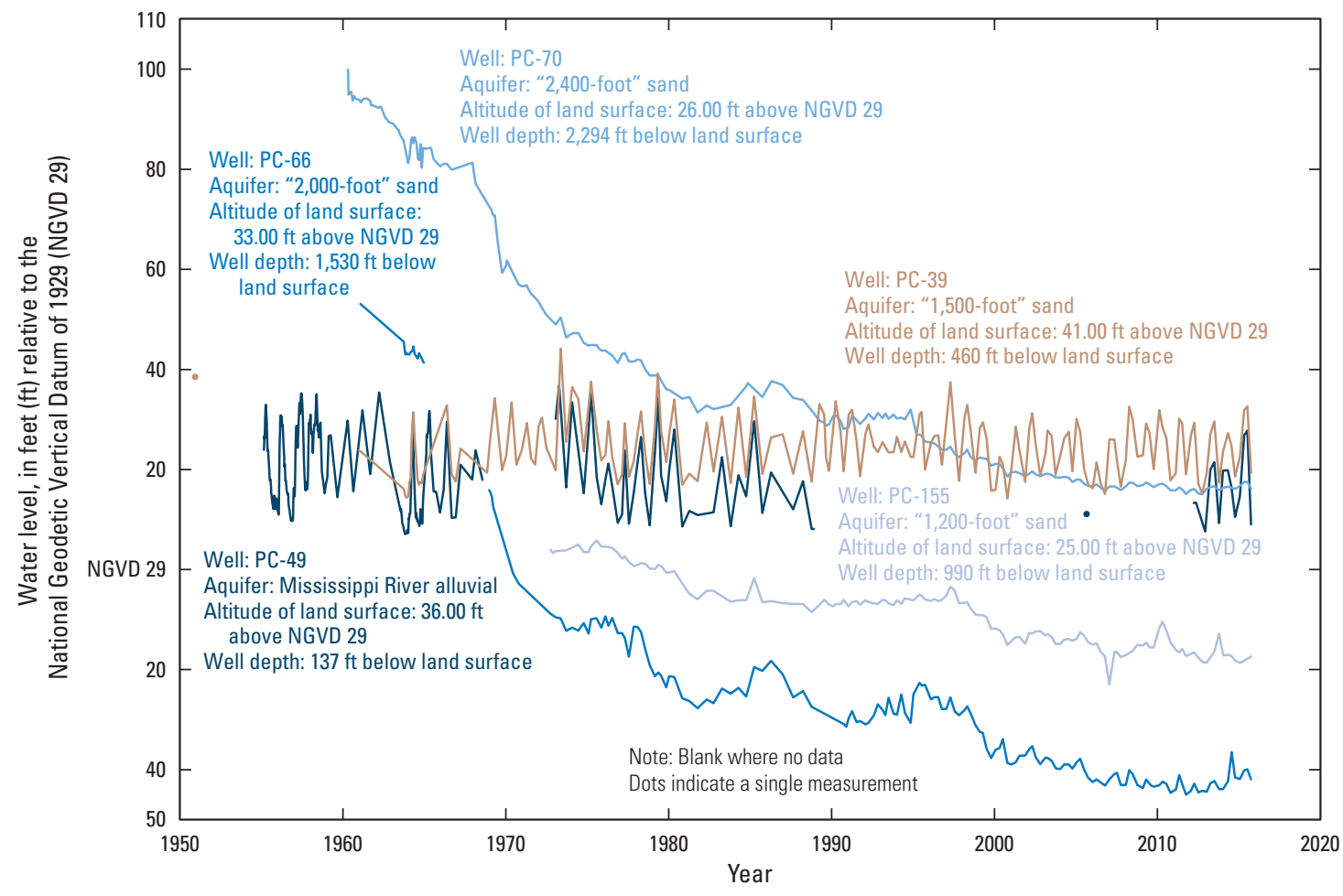

Figure 4. Water levels in wells PC-49 screened in the Mississippi River alluvial aquifer, PC-155 screened in the "1,200-foot" sand, PC-39 screened in the "1,500-foot" sand, PC-66 screened in the "2,000-foot" sand, and PC-70 screened in the "2,400-foot" sand in Pointe Coupee Parish, Louisiana (see fig. 1 for well locations; U.S. Geological Survey, 2017b). 


\section{Jasper Equivalent Aquifer System}

The Jasper equivalent aquifer system comprises the " 2,000 foot," "2,400-foot," and "2,800-foot," sands of the Baton Rouge area (Griffith, 2003). The "2,000-foot" sand is generally present throughout Pointe Coupee Parish with the altitude of the base present from about $500 \mathrm{ft}$ below NGVD 29 in the northern part of the parish to $1,900 \mathrm{ft}$ below NGVD 29 near the southern border and with thicknesses from less than $50 \mathrm{ft}$ to about $200 \mathrm{ft}$. The " 2,400 foot" sand is also generally present throughout the parish with the aquifer top present from an altitude of about $500 \mathrm{ft}$ below NGVD 29 in the northern part of the parish to 2,400 ft below NGVD 29 near the southern border. Thickness of the freshwater-bearing area ranges from 0 to $300 \mathrm{ft}$ (Winner and others, 1968).

Water levels at well PC-66 (USGS site number $303556091234001)$ screened in the "2,000-foot" sand and at well PC-70 (USGS site number 303402091325501 ) screened in the "2,400-foot" sand (fig. 4) have declined about $80 \mathrm{ft}$ or more from the early 1960 s to the 2010 s when levels stabilized and began to increase slightly.

State well-registration records listed 105 active water wells screened in the Jasper equivalent aquifer system in Pointe Coupee Parish in 2017: 58 public-supply wells, 39 domestic wells, 4 industrial wells, and 4 irrigation wells. Well depths ranged from 469 to $2,343 \mathrm{ft}$ below land surface, and reported yields ranged from 15 to $1,064 \mathrm{gal} / \mathrm{min}$ (Louisiana Department of Natural Resources, 2017). In 2014, about $4.00 \mathrm{Mgal} / \mathrm{d}$ were withdrawn from the Jasper equivalent aquifer system in Pointe Coupee Parish: $2.62 \mathrm{Mgal} / \mathrm{d}$ for public supply, $1.28 \mathrm{Mgal} / \mathrm{d}$ for industry, $0.10 \mathrm{Mgal} / \mathrm{d}$ for rural domestic, and less than 0.01 Mgal/d for livestock (Collier, 2018).

\section{Groundwater Quality}

Groundwater samples were collected from 37 wells screened in the Evangeline equivalent aquifer system during 1940-2006 and 71 wells screened in the Jasper equivalent aquifer system during 1942-87 as part of a long-term monitoring program for the State's groundwater resources (table 3) (USGS, 2017b). Median values for hardness were within the soft ${ }^{2}$ range for both aquifer systems. Sulfate and chloride concentrations were below the U.S. Environmental Protection Agency's Secondary Maximum Contaminant Levels (SMCLs) ${ }^{3}$ for 100 percent of samples from both aquifers. Iron and dissolved-solids concentrations were within SMCLs for at least 88 percent of samples. The median value for color was at the SMCL of 15 platinum cobalt units for the Jasper equivalent aquifer system and below the SMCL for the Evangeline equivalent aquifer system.

\footnotetext{
${ }^{2}$ Hardness ranges, expressed as milligrams per liter of calcium carbonate, are as follows: 0-60, soft; 61-120, moderately hard; 121-180, hard; greater than 180, very hard (Hem, 1985).

${ }^{3}$ The SMCLs are Federal guidelines regarding cosmetic effects (such as tooth or skin discoloration), aesthetic effects (such as taste, odor, or color), or technical effects (such as damage to water equipment or reduced effectiveness of treatment for other contaminants) of potential constituents of drinking water. SMCLs were established as guidelines by the U.S. Environmental Protection Agency (2016).
}

Table 3. Summary of selected water-quality characteristics for 37 wells screened in the Evangeline equivalent aquifer system and 71 wells screened in the Jasper equivalent aquifer system in Pointe Coupee Parish, Louisiana (U.S. Geological Survey, 2017b).

[Values are in milligrams per liter, except as noted. ${ }^{\circ} \mathrm{C}$, degrees Celsius; $\mu \mathrm{S} / \mathrm{cm}$, microsiemens per centimeter; $\mathrm{SU}$, standard unit; $\mathrm{CaCO}_{3}$, calcium carbonate; $\mu \mathrm{g} / \mathrm{L}$, micrograms per liter; <, less than; SMCL, Secondary Maximum Contaminant Level established by the U.S. Environmental Protection Agency (2016); NA, not applicable]

\begin{tabular}{|c|c|c|c|c|c|c|c|c|c|c|c|c|c|}
\hline & $\begin{array}{l}\text { Temper- } \\
\text { ature } \\
\left({ }^{\circ} \mathrm{C}\right)\end{array}$ & $\begin{array}{l}\text { Color } \\
\text { (plati- } \\
\text { num } \\
\text { cobalt } \\
\text { units) }\end{array}$ & $\begin{array}{c}\text { Specific } \\
\text { conduc- } \\
\text { tance, } \\
\text { field } \\
(\mu \mathrm{S} / \mathrm{cm} \text { at } \\
\left.25^{\circ} \mathrm{C}\right)\end{array}$ & $\begin{array}{c}\text { pH, field } \\
\text { (SU) }\end{array}$ & $\begin{array}{c}\text { Hard- } \\
\text { ness } \\
\text { (as } \\
\mathrm{CaCO}_{3} \text { ) }\end{array}$ & $\begin{array}{c}\text { Cal- } \\
\text { cium, } \\
\text { filtered } \\
\text { (as Ca) }\end{array}$ & $\begin{array}{l}\text { Mag- } \\
\text { nesium, } \\
\text { filtered } \\
\text { (as Mg) }\end{array}$ & $\begin{array}{l}\text { Sodium, } \\
\text { filtered } \\
\text { (as Na) }\end{array}$ & $\begin{array}{l}\text { Chlo- } \\
\text { ride, } \\
\text { filtered } \\
\text { (as CI) }\end{array}$ & $\begin{array}{l}\text { Sulfate, } \\
\text { filtered } \\
\text { (as } \mathrm{SO}_{4} \text { ) }\end{array}$ & $\begin{array}{l}\text { Iron, } \\
\text { filtered, } \\
\text { in } \mu \mathrm{g} / \mathrm{L} \\
\text { (as Fe) }\end{array}$ & $\begin{array}{l}\text { Man- } \\
\text { ganese, } \\
\text { filtered, } \\
\text { in } \mu \mathrm{g} / \mathrm{L} \\
\text { (as Mn) }\end{array}$ & $\begin{array}{l}\text { Dis- } \\
\text { solved } \\
\text { solids, } \\
\text { filtered }\end{array}$ \\
\hline \multicolumn{14}{|c|}{ Evangeline equivalent aquifer system (1940-2006) } \\
\hline Median & 24 & 5 & 339 & 8.2 & 9 & 1.9 & 0.2 & 69 & 4.3 & 10 & 80 & 61 & 225 \\
\hline 10th percentile & 20.7 & 0 & 237 & 7.2 & $<1.2$ & 0.3 & $<0.02$ & 30 & 2.6 & 7 & 14.3 & $<7.1$ & 183 \\
\hline 90th percentile & 26 & 14.5 & 462 & 9.0 & 64.4 & 12.5 & 3.9 & 96 & 21.2 & 12 & 700 & 118 & 292 \\
\hline Number of samples & 23 & 22 & 36 & 28 & 43 & 26 & 26 & 26 & 43 & 31 & 16 & 14 & 22 \\
\hline $\begin{array}{l}\text { Percentage of } \\
\text { samples that } \\
\text { do not exceed } \\
\text { SMCLs }\end{array}$ & NA & 95 & NA & 71 & NA & NA & NA & NA & 100 & 100 & 88 & 43 & 100 \\
\hline \multicolumn{14}{|c|}{ Jasper equivalent aquifer system (1942-87) } \\
\hline Median & 29 & 15 & 414 & 8.8 & 5 & 1.2 & 0.2 & 97 & 6 & 7 & 70 & 10 & 261 \\
\hline 10 th percentile & 23.5 & 5 & 283 & 7.7 & 1.6 & $<0.1$ & 0 & 74 & 3.0 & $<0.3$ & 20 & $<10$ & 215 \\
\hline 90th percentile & 31.5 & 80 & 842 & 9.2 & 12.2 & 4 & 0.8 & 185 & 58.7 & 12 & 344 & 90 & 484 \\
\hline Number of samples & 58 & 82 & 82 & 98 & 99 & 57 & 56 & 56 & 90 & 62 & 57 & 35 & 48 \\
\hline $\begin{array}{l}\text { Percentage of } \\
\text { samples that } \\
\text { do not exceed } \\
\text { SMCLs }\end{array}$ & NA & 54 & NA & 33 & NA & NA & NA & NA & 100 & 100 & 88 & 77 & 94 \\
\hline SMCLs & NA & 15 & NA & $6.5-8.5$ & NA & NA & NA & NA & 250 & 250 & 300 & 50 & 500 \\
\hline
\end{tabular}




\section{Surface-Water Resources}

Numerous surface-water resources in Pointe Coupee Parish are present in four regional drainage subbasins: the Atchafalaya subbasin (Hydrologic Unit Code [HUC] 08080101) in the western part of the parish, the Lower Red subbasin (HUC 08040301) in the northern extremity of the parish, the Lower Mississippi-Baton Rouge subbasin (HUC 08070100) along the eastern border, and the Lower Grand subbasin (HUC 08070300) in the southeastern corner of the parish (fig. 1; USGS, 2017b). As a result of extensive levees, little water flows into the parish by way of streams; however, the parish is flanked by the Atchafalaya and Mississippi Rivers on its western and eastern borders, respectively. In 2014, $1.59 \mathrm{Mgal} / \mathrm{d}$ were withdrawn from miscellaneous surface waters in Pointe Coupee Parish (table 1): $1.59 \mathrm{Mgal} / \mathrm{d}$ for aquaculture and less than $0.01 \mathrm{Mgal} / \mathrm{d}$ for livestock (table 2) (Collier, 2018).

\section{Lower Red and Atchafalaya Subbasins}

The Atchafalaya River begins near the northern border of the parish where the Red River merges with water diverted from the Mississippi River. This merge point begins the Atchafalaya subbasin. The average streamflow, upstream from Pointe Coupee Parish, for the Red River at Alexandria (USGS site number 07355500; fig. 1 index map) was 30,770 cubic feet per second $\left(\mathrm{ft}^{3} / \mathrm{s}\right)$ during $1928-82$ (Carlson and others, 1983). The annual average streamflow for the Atchafalaya River at Simmesport (USGS site number 07381490) was $218,400 \mathrm{ft}^{3} / \mathrm{s}$ during 2009-15. During this period, the highest monthly average streamflow at Simmesport occurred during May $\left(354,300 \mathrm{ft}^{3} / \mathrm{s}\right)$ and the lowest during November $\left(105,600 \mathrm{ft}^{3} / \mathrm{s}\right)$ (USGS, 2017b).

\section{Lower Mississippi-Baton Rouge Subbasin}

The Mississippi River is sustained by drainage from more than 40 percent of the conterminous United States but drains little land area in Pointe Coupee Parish because of levees along the river (Demcheck and others, 2004). The average streamflow of the Mississippi River near Red River Landing near the north end of Pointe Coupee Parish (USGS site number 07373291; fig. 1) was about $460,000 \mathrm{ft}^{3} / \mathrm{s}$ for the period 1928-76 (Wells, 1980). In 2014, $322.12 \mathrm{Mgal} / \mathrm{d}$ were withdrawn from the Mississippi River for power generation (table 2) (Collier, 2018).

\section{Lower Grand Subbasin}

Water bodies of the Lower Grand subbasin include Bayou Grosse Tete, Bayou Tommy, Cholpe Bayou, Bayou Poydras, Bayou Fordoche, other small streams, and the False River oxbow lake. Little streamflow data for these streams are available. False River is a former channel of the Mississippi River that was formed around 300 years ago or more. The lake is about 22 miles long, is about 3,212 acres, and has an average depth of $21 \mathrm{ft}$ and a maximum depth of $65 \mathrm{ft}$ (Louisiana Department of Wildlife and Fisheries, 2016). The lake is used for various recreational activities.

Table 4. Summary of selected water-quality characteristics for samples from the Mississippi River near Saint Francisville and the Atchafalaya River at Simmesport near Pointe Coupee Parish, Louisiana (U.S. Geological Survey, 2017b).

[Values are in milligrams per liter, except as noted. $\mu \mathrm{S} / \mathrm{cm}$, microsiemens per centimeter; ${ }^{\circ} \mathrm{C}$, degrees Celsius; $\mathrm{SU}$, standard unit; $\mathrm{CaCO}_{3}$, calcium carbonate; $\mu \mathrm{g} / \mathrm{L}$, micrograms per liter; <, less than; SMCL, Secondary Maximum Contaminant Level established by the U.S. Environmental Protection Agency (2016); NA, not applicable]

\begin{tabular}{|c|c|c|c|c|c|c|c|c|c|c|c|}
\hline & $\begin{array}{c}\text { Specific } \\
\text { conduc- } \\
\text { tance, field } \\
(\mu \mathrm{S} / \mathrm{cm} \text { at } \\
\left.25^{\circ} \mathrm{C}\right)\end{array}$ & $\begin{array}{l}\text { Dis- } \\
\text { solved } \\
\text { oxygen }\end{array}$ & $\begin{array}{l}\text { pH, } \\
\text { field } \\
\text { (SU) }\end{array}$ & $\begin{array}{l}\text { Hard- } \\
\text { ness } \\
\text { (as } \\
\mathrm{CaCO}_{3} \text { ) }\end{array}$ & $\begin{array}{l}\text { Calcium, } \\
\text { filtered } \\
\text { (as Ca) }\end{array}$ & $\begin{array}{l}\text { Mag- } \\
\text { nesium, } \\
\text { filtered } \\
\text { (as Mg) }\end{array}$ & $\begin{array}{l}\text { Sodium, } \\
\text { filtered } \\
\text { (as Na) }\end{array}$ & $\begin{array}{l}\text { Chlo- } \\
\text { ride, } \\
\text { filtered } \\
\text { (as CI) }\end{array}$ & $\begin{array}{l}\text { Sulfate, } \\
\text { filtered } \\
\text { (as } \mathrm{SO}_{4} \text { ) }\end{array}$ & $\begin{array}{c}\text { Iron, } \\
\text { filtered, } \\
\text { in } \mu \mathrm{g} / \mathrm{L} \\
\text { (as Fe) }\end{array}$ & $\begin{array}{c}\text { Dis- } \\
\text { solved } \\
\text { solids, } \\
\text { filtered }\end{array}$ \\
\hline \multicolumn{12}{|c|}{ Mississippi River near Saint Francisville (1954-2013)'1 } \\
\hline Median & 378 & 8.6 & 7.7 & 140 & 39 & 11.7 & 18 & 20 & 47 & 12.6 & 230 \\
\hline 90th percentile & 470 & 11.3 & 8 & 178 & 46.5 & 15.7 & 27.3 & 30 & 68 & 58 & 286 \\
\hline Number of samples & 841 & 529 & 982 & 966 & 666 & 670 & 584 & 976 & 974 & 511 & 1,231 \\
\hline $\begin{array}{l}\text { Percentage of samples } \\
\text { that do not exceed } \\
\text { SMCLs }\end{array}$ & NA & NA & 100 & NA & NA & NA & NA & 100 & 100 & 100 & 100 \\
\hline 90th percentile & 471 & 10.4 & 8.1 & 160 & 42.3 & 13 & 33.3 & 42 & 59 & 75 & 279 \\
\hline Number of samples & 60 & 55 & 62 & 61 & 58 & 59 & 58 & 62 & 62 & 16 & 61 \\
\hline $\begin{array}{l}\text { Percentage of samples } \\
\text { that do not exceed } \\
\text { SMCLs }\end{array}$ & NA & NA & 98 & NA & NA & NA & NA & 100 & 100 & 100 & 100 \\
\hline SMCLs & NA & NA & $6.5-8.5$ & NA & NA & NA & NA & 250 & 250 & 300 & 500 \\
\hline
\end{tabular}




\section{Surface-Water Quality}

Water samples were collected from the Atchafalaya River at Simmesport (USGS site number 07381490) during 1952-77 and the Mississippi River near Saint Francisville (USGS site number 07373420) during 1954-2013 as part a long-term program to monitor the State's surface-water resources (fig. 1; table 4) (USGS, 2017b). Nearly all concentrations in samples from both rivers were below SMCLs. Median values for $\mathrm{pH}$ and for calcium, magnesium, sodium, and chloride concentrations were similar for both rivers. However, there were larger differences in median values for sulfate, iron, and dissolved-solids concentrations between the two rivers. The median value for hardness in Atchafalaya River samples was in the moderately hard range, whereas the median value for hardness in Mississippi River samples was in the hard range. Median values for dissolved-oxygen concentrations were at least $8.0 \mathrm{mg} / \mathrm{L}$ for both rivers; $5 \mathrm{mg} / \mathrm{L}$ is generally considered a minimum value for a diverse population of fresh, warmwater biota, including sport fish (Louisiana Department of Environmental Quality, 2008).

\section{References Cited}

Carlson, D.D., Stallworth, G.R., Dantin, L.J., and Stuart, C.G., 1983, Water resources data, Louisiana, water year 1983, volume 1, central and northern Louisiana: U.S. Geological Survey Water-Data Report LA-83-1.

Collier, A.L., 2018, Water withdrawals by source and category in Louisiana Parishes, 2014-2015: U.S. Geological Survey data release, https:/doi. org/10.5066/F78051VM.

Demcheck, D.K., Tollett, R.W., Mize, S.V., Skrobialowski, S.C., Fendick, R.B., Jr., Swarzenski, C.M., and Porter, S., 2004, Water quality in the Acadian-Pontchartrain Drainages, Louisiana and Mississippi, 19992001: U.S. Geological Survey Circular 1232, 47 p. [Also available at https://doi.org/10.3133/cir1232.]

Griffith, J.M., 2003, Hydrogeologic framework of southeastern Louisiana: Louisiana Department of Transportation and Development Water Resources Technical Report No. 72, 21 p. [Also available at https://wise. er.usgs.gov/dp/pdfs/TR72.pdf.]

Griffith, J.M., and Lovelace, J.K., 2003, Louisiana ground-water map no. 15-Potentiometric surface of the "1,200-foot" sand of the Baton Rouge area, Louisiana, spring 2001: U.S. Geological Survey Water-Resources Investigations Report 03-4020, 2 sheets. [Also available at https://wise. er.usgs.gov/dp/pdfs/WRI_03-4020.pdf.]

Hem, J.D., 1985, Study and interpretation of the chemical characteristics of natural water ( $3 \mathrm{~d}$ ed.): U.S. Geological Survey Water-Supply Paper 2254, 264 p., accessed February 20, 2013, at http://pubs.er.usgs.gov/ publication/wsp2254.

Louisiana Department of Environmental Quality, 2008, Environmental Regulatory Code, Title 33, Part IX, Subpart 1: Baton Rouge, Louisiana Department of Environmental Quality, accessed June 9, 2009, at https://www.deq.louisiana.gov/resources/category/regulations-lactitle-33.

Louisiana Department of Natural Resources, 2017, Strategic Online Natural Resources Information System (SONRIS): Louisiana Department of Natural Resources database, accessed June 12, 2017, at http://sonris. $\mathrm{com} /$.

Louisiana Department of Wildlife and Fisheries, 2016, Waterbody Management Plan Series, False River, lake history and management issues: Office of Fisheries, Inland Fisheries Section Part VI-A, accessed December 22, 2017, at https:/www.wlf.louisiana.gov/resources/ category/freshwater-inland-fish/3\#1.
Sargent, B.P., 2011, Water use in Louisiana, 2010: Louisiana Department of Transportation and Development Water Resources Special Report No. 17, 135 p. [Also available at https://wise.er.usgs.gov/dp/pdfs/ WaterUse2010.pdf.]

Smoot, C.W., 1988, Louisiana hydrologic atlas map no. 3-Altitude of the base of freshwater in Louisiana: U.S. Geological Survey Water-Resources Investigations Report 86-4314, 1 sheet, accessed November 2, 2011, at https://doi.org/10.3133/wri864314.

Stuart, C.G., Knochenmus, D., and McGee, B.D., 1994, Guide to Louisiana's ground-water resources: U.S. Geological Survey WaterResources Investigations Report 94-4085, 55 p., accessed September 29, 2020, at https://doi.org/10.3133/wri944085.

U.S. Environmental Protection Agency, 2016, Secondary Drinking Water Standards - Guidance for nuisance chemicals, accessed April 13, 2016 , at https:/www.epa.gov/dwstandardsregulations/secondary-drinkingwater-standards-guidance-nuisance-chemicals.

U.S. Geological Survey [USGS], 2017a, U.S. Geological Survey Water Resources Cooperative Program-Louisiana Water Use Program, accessed August 24, 2017, at https://www.usgs.gov/centers/lmg-water/ science/water-use-louisiana?qt-science_center_objects=0\#qt-science center_objects.

U.S. Geological Survey [USGS], 2017b, USGS water data for the Nation: U.S. Geological Survey National Water Information System database, accessed February 28, 2017, at https://doi.org/10.5066/F7P55KJN.

Wells, F.C., 1980, Hydrology and water quality of the lower Mississippi River: Louisiana Department of Transportation and Development, Office of Public Works Water Resources Technical Report No. 21, 83 p. [Also available at https://wise.er.usgs.gov/dp/pdfs/TR21.pdf.]

Winner, M.D., Forbes, M.J., Jr., and Broussard, W.L., 1968, Water Resources of Pointe Coupee Parish, Louisiana: Department of Conservation, Louisiana Geological Survey and Department of Public Works Water Resources Bulletin No. 11, 110 p. 11 pls.

This fact sheet has been prepared by the USGS, in cooperation with the Louisiana Department of Transportation and Development (DOTD), as part of a program to document water use, availability, and quality in the parishes of Louisiana. Information on the availability, past and current water use, use trends, and water quality from groundwater and surface-water sources in the parish is presented here. Previously published reports (see References Cited section) and data stored in the USGS National Water Information System (USGS, 2017b) are the primary sources of the information presented here. Special thanks are given to Doug Taylor, Director, and Zahir "Bo" Bolourchi (retired), DOTD Cooperative Program with the USGS.

\section{By Vincent $E$. White}

\section{For additional information, contact:}

Director, USGS Lower Mississippi-Gulf Water Science Center 3535 S. Sherwood Forest Blvd., Suite 120

Baton Rouge, LA 70816

E-mail: gs-w-lmg_center_director@usgs.gov

Fax: (225) 298-5490

Telephone: (225) 298-5481

Home Page: https://www.usgs.gov/centers/lmg-water/ 